\title{
RESPONSE OF TOMATO (Lycopersicon esculentum Mill.) CULTIVARS TO NITROGEN LEVELS
}

\author{
Nasir Mehmood, ${ }^{\mathrm{a}}$ Gohar Ayub, ${ }^{\mathrm{a}}$ Ihteram Ullah, ${ }^{\mathrm{b}, \mathrm{c}^{*}}$ Naveed Ahmad, ${ }^{\mathrm{a}}$ Muhammad Noor, ${ }^{\mathrm{b}}$, Amir Muhammad Khan ${ }^{\mathrm{c}}$ \\ Saeed Ahmad, ${ }^{\mathrm{a}}$ Ammara Saeed ${ }^{\mathrm{a}}$ and Farzana ${ }^{\mathrm{a}}$
}

\footnotetext{
${ }^{a}$ Department of Horticulture, KP Agricultural University, Peshawar, Pakistan.

${ }^{\mathrm{b}}$ Department of Plant Breeding and Genetics, KP Agricultural University, Peshawar, Pakistan.

${ }^{c}$ Department of Botany, Kohat University of Science and Technology, Kohat, Pakiistan.

*Corresponding author: ihterampbg@gmail.com
}

The influence of nitrogen levels on tomato cultivars was evaluated at New Developmental Farm (NDF), Khyber Pakhtunkhwa Agricultural University Peshawar in summer, 2011. The experiment was laid out in Randomized Complete Block (RCBD) with split plot arrangement. There were two factors i.e. nitrogen levels $\left(0,100,150\right.$ and $\left.200 \mathrm{~kg} \mathrm{ha}^{-1}\right)$ which were allotted to main plots and tomato cultivars (Roma, Roma VF, Super classic, Bambino and Riogrand) assigned to sub plots. A total of twenty treatments were replicated thrice. Maximum days to flowering (44.53 days), days to fruiting (50.13 days) and fruit width $(5.02 \mathrm{~cm})$ was obtained when nitrogen was applied at $200 \mathrm{~kg} \mathrm{ha}^{-1}$. The tallest plants $(63.09 \mathrm{~cm})$, number of branches $(6.73)$, maximum number of fruits (25.53), fruit length $(5.97 \mathrm{~cm})$ and yield $\left(27.54 \mathrm{tha}^{-1}\right)$ was produced by the plots fertilized with $150 \mathrm{~kg} \mathrm{~N} \mathrm{ha}^{-1}$, while minimum days to flowering (37.93 days), days to fruiting (44.67), number of fruits $(21.82)$, fruit width $(4.45 \mathrm{~cm})$ and yield $\left(21.50 \mathrm{t} \mathrm{ha}^{-1}\right)$ were obtained from control plots. Maximum days to flowering (43.33 days) were taken by cultivar Bambino whereas, minimum (39.75 days) were taken by cultivar Riogrand. Similarly in case of cultivars, Bambino cultivar produced longer fruit $(6.04 \mathrm{~cm})$ while Roma VF produced smaller fruit $(5.27 \mathrm{~cm})$. Maximum fruit yield $\left(29.65 \mathrm{t} \mathrm{ha}^{-1}\right)$ was produced by Riogrand whereas; poor yield $\left(19.24 \mathrm{t} \mathrm{ha}^{-1}\right)$ was produced by Roma. Maximum number of fruit plant ${ }^{-1}$ (27.61) was produced by Riogrand whereas; minimum (18.76) was produced by Roma VF. Among the various treatments studied in the experiment, it is suggested that Riogrand with the application of $150 \mathrm{~kg} \mathrm{~N} \mathrm{ha}^{-1}$ can be used in Peshawar valley for better growth and yield of tomato.

Keywords: Cultivars; Tomato; Nitrogen; Yield Introduction

Tomato (Lycopersicon esculentum Mill.) belongs to the family solanaceae, which is most wellliked and commonly grown vegetable in all over the world. Next to potato, tomato is the most widely produced and cultivated crop. It is a summer vegetable so can tolerate high temperature and drought and grown on various soil and a range of atmospheric conditions. About 500 B.C. tomato was grown by the Indians long ago before the arrival of Spaniards while it is native of west coast of South America [1]. The European imported tomato to subcontinent of the Indo-Pak in the second half of 19th century. Tomato is grown all over the world where as China, USA, Turkey, Italy, Egypt, India, Spain, Brazil, Iran and Mexico are the major producers [2]. Tomato is very popular all over the world which has gained the position of mostly consumed vegetable among the other vegetables [3]. In Pakistan, tomato was cultivated on 24,144 hectares area, which produced 275241 tons tomatoes during 2008-09. Area under cultivation of tomato in Khyber Pakhtunkhwa was 4230 hectares with a total production of about 51,062 tons per anum. In Peshawar, area under tomato cultivation was 944 acres produced 2.978 tons of tomato. The area has been increased by 54\% during the last 17 years in Pakistan (MINFAL, 2008-2009).
Nutrient supply and environment mainly affect the productivity of the crop. Some of these nutrients are supplied by soil while, other are to be added from the external source in the form of organic and inorganic. Tomato crop requires heavy manure and sufficient amount of fertilizer for heavy yield. For improving plant growth and development, use of organic and inorganic manure is important which improve plant growth directly by providing nutrients [4]. Fruit yield of tomato has been influenced by different levels of nitrogen and phosphorous that's why it needs greater attention to apply these nutrients in proper amount [5-7]. Nitrogen is an essential constituent of proteins and chlorophyll and is present in many other compounds of great physiological importance such as nucleotides, phosphatides, alkaloids, enzymes, hormones, vitamins etc. It is thus, the very basic constituent of life. It promotes leaf, stem and vegetative growth. It improves quality, succulence of leafy vegetables and fodder crops and governs to a considerable degree, the utilization of potassium, phosphorus and other elements. Commercially production of tomato needs proper fertilizer and water management for high yield. On coarse-textured and low organic-matter soils nitrogen mainly limit 
the growth of the crop due to leaching and denitrification [8].

Lack of varieties for specific zones and low resistance against different diseases in varieties reduce the tomato yield per unit area. Limited amount of locally approved varieties and lack of local tomato based seed industry further helps in reduction of tomato yield. In order to increase the yield per unit area and period of production, better cultivars need to be developed. The easiest way to achieve this goal is to introduce exotic varieties, evaluate them under local climatic conditions, then release them to farmers or use them in genetic crosses and select promising lines from the segregating generation having the growth habits capacity, high yield, tolerance to heat stress, tolerance to disease with better fruit size.

Hence, keeping above points in view the present investigation was undertaken at Horticulture Research Farm, Khyber Pakhtunkhwa Agricultural University Peshawar with the following objectives:

1. To find the best cultivar of tomato for higher yield in Peshawar.

2. To find the optimum level of nitrogen for better production of tomato.

\section{Materials and Methods}

An experiment entitled "Response of tomato cultivars to nitrogen levels" was conducted at New Developmental Farm (NDF), Department of Horticulture, Khyber Pakhtunkhwa Agricultural University Peshawar in summer, 2011. The experiment was laid out in randomized complete block design with split plot arrangement. There were two factors i.e., Nitrogen levels $(0,100,150$ and 200 $\mathrm{kg} \mathrm{ha}{ }^{-1}$ ) and tomato cultivars (Roma VF, Roma, Super Classic, Bambino and Riogrand). Nitrogen levels were kept in main plot while tomato cultivars were assigned to sub plot. A total of twenty treatments were replicated thrice. Soil samples were taken from different points randomly from the experimental field at $15-30 \mathrm{~cm}$ depth before other fertilizer application for chemical analysis. Different values obtained were nitrogen $(0.166 \%)$, lime (11.4\%), soil $\mathrm{pH}$ (7.55), EC dms ${ }^{-1}(0.27)$ and texture was silty loam. Soil was ploughed up thoroughly and then was leveled through leveling machine. Well rotten farm yard manure was mixed with the soil. Recommended dose of phosphorus $\left(80 \mathrm{~kg} \mathrm{ha}^{-1}\right)$ and potassium $\left(40 \mathrm{~kg} \mathrm{ha}^{-1}\right)$ were incorporated into the soil at the time of transplanting of seedling. The source of potash was sulphate of potash $(50 \%)$ while that of phosphorous was single super phosphate (18\%). The source of nitrogen in the experiment was urea (46\%), which was applied in three split doses i.e. first dose at the time of transplantation and the remaining two after transplantation before flowering at ten days interval.

The seeds of tomato cultivars used in the experiment were taken from the market, which were sown in nursery bed on 19th February. The seed were watered after sowing. After that the water was applied according to the requirements. The seedling of obviously equal height and vigor was transplanted on 5th April 2011. Seedling was immediately irrigated. Ridges were made manually at proper height. A space of $60 \mathrm{~cm}$ was kept between ridges and $30 \mathrm{~cm}$ between plants. Plot size was kept as 1.8 $\mathrm{m}^{2}$. Five cultivars of tomato (Lycopersicon esculentum Mill.) and four nitrogen levels were assigned to plots in accordance with the field layout. Subsequent irrigations were applied when required. All the standard cultural practices i.e. hoeing, weeding etc were performed regularly. The data were analyzed using MSTATC software and the significant means were separated by LSD at 0.05 probability level. [9].

\section{Results and Discussion \\ Plant height $(\mathbf{c m})$}

The tallest $(63.09 \mathrm{~cm})$ plants were produced by Bambino, while the shortest plants $(51.87 \mathrm{~cm})$ were produced by Super classic. Similarly in terms of nitrogen, the tallest $(58.96 \mathrm{~cm})$ plants were obtained from the plots fertilized with $150 \mathrm{~kg} \mathrm{ha}^{-1}$, while the shortest plants $(52.81 \mathrm{~cm})$ were produced by the control plots. While studying their interaction the tallest $(65.40 \mathrm{~cm})$ plants were obtained from the plots fertilized with $150 \mathrm{~kg} \mathrm{ha}^{-1}$ nitrogen by the cultivar Riogrand, while the shortest $(44.70 \mathrm{~cm})$ plants were produced by Super classic in control treatment (Table $1)$.

Plant height is a function of genetic as well as environmental conditions. Since nitrogen increase the vegetative growth of the plants [10], thus it increased with incremental increase in nitrogen. Plant height of tomato was significantly increased by different levels of nitrogen. Haque et al. [11] reported that 120 and $180 \mathrm{~kg} \mathrm{~N} \mathrm{ha}^{-1}$ produced the plants with similar plant height. The present results are in agreement with those of Ali et al. [12]; Mondal and Gaffer [13]; Gaffer and Razzaque [14], who reported that nitrogen significantly, increased plant height.

\section{Number of branches Plant ${ }^{-1}$}

More number of branches (6.73) was obtained when $150 \mathrm{~kg} \mathrm{ha}^{-1}$ nitrogen was applied, while less number of branches (5.95) was obtained from control plots. In case of cultivars, Riogrand produced more branches (6.98) whereas, lesser number of branches were recorded (5.71) for cultivar Super classic. Thus, Riogrand has a genetic potential 
for more number of branches as compare to the other varieties. Numbers of branches were significantly affected by nitrogen levels and cultivars (Table 1). Interaction between different tomato cultivars and nitrogen levels was non significant.

Number of branches gradually increased with the increase of nitrogen [15]. Our observations are in line with Dass and Mishra [16] who observed the highest number of branches (15.5) at $150 \mathrm{~kg} \mathrm{~N}^{-}$ 1. Similarly, a linear increase in the number of branches plant ${ }^{-1}$ in chillies with increase in nitrogen levels was also noticed by Khan and Suryanarayana [17].

\section{Days to flowering}

Maximum days to flowering (43.33) were observed in tomato cultivar Bambino whereas, minimum (39.75 days) observed in tomato cultivar Riogrand. Similarly, flowering was delayed (44.53 days) when nitrogen was used at the rate of $200 \mathrm{~kg}$ $\mathrm{ha}^{-1}$, while early flowering (37.93 days) was recorded in controlled plots. Thus, application of the nitrogen delayed flowering (Table 1).

Flowering is perhaps the most sensitive character to the nitrogen fertilizer. Hence increase nitrogen levels increases the vigor of the plant, which ultimately increases the vegetative period and delayed flowering [11]. Similarly, Law and Egharevba [18] reported that maximum days to flowering were observed as fertilizer level increased. The results were also in line with those of AddaeKahya and Norman [19] while studying the effect of nitrogen on tomato cultivars i.e. Cherry and Pearson.

\section{Days to fruiting}

In case of nitrogen, early fruiting (44.67 days) was recorded in control plots, while fruiting was delayed (50.13 days) when $200 \mathrm{~kg} \mathrm{ha}^{-1}$ nitrogen was used. Nitrogen increases the vegetative phase and delayed flowering which also delayed fruiting. Regarding cultivars, Riogard was early fruiting (45.75 days) while Bambino was late fruiting (49.42 days) cultivar (Table 1). Interaction between the two factors was regarded as non significant.

The difference in days to flowering among the tomato cultivars may be due to the different genetic makeup of the cultivars. The results are in line with those obtained by Addae-Kagay and Norman [19] while studying the effect of nitrogen of different tomato varieties. Nitrogen application, thus, delayed fruiting in tomato varieties. High nitrogen level, however, can stimulate excessive vegetative growth which can delay fruit setting and maturation [20].

\section{Number of Fruits Plant $^{-1}$}

Maximum number of fruit plant ${ }^{-1}$ (27.61) was produced by Riogrand whereas; minimum
(18.76) was produced by Roma VF. In case of nitrogen levels, the highest number of fruit plant ${ }^{-1}$ (25.53) was obtained with the application of $150 \mathrm{~kg}$

Table-1: Plant height, leaves plant ${ }^{-1}$, days to flowering and days to fruiting of tomato cultivars as affected by different $\mathrm{N}$ levels.

\begin{tabular}{|l|c|c|c|c|}
\hline Treatments & $\begin{array}{c}\text { Plant } \\
\text { Height } \\
\text { N Levels }\end{array}$ & $\begin{array}{c}\text { Leaves } \\
\text { plant }^{-1}\end{array}$ & $\begin{array}{c}\text { Days to } \\
\text { flowering }\end{array}$ & $\begin{array}{c}\text { Days to } \\
\text { fruiting }\end{array}$ \\
\hline 0 & $52.81 \mathrm{c}$ & $5.95 \mathrm{~b}$ & $37.93 \mathrm{~d}$ & $44.67 \mathrm{c}$ \\
\hline 100 & $56.24 \mathrm{~b}$ & $6.17 \mathrm{ab}$ & $39.47 \mathrm{c}$ & $45.73 \mathrm{c}$ \\
\hline 150 & $58.96 \mathrm{a}$ & $6.73 \mathrm{a}$ & $42.13 \mathrm{~b}$ & $47.87 \mathrm{~b}$ \\
\hline 200 & $56.46 \mathrm{ab}$ & $6.29 \mathrm{ab}$ & $44.53 \mathrm{a}$ & $50.13 \mathrm{a}$ \\
\hline $\begin{array}{l}\text { LSD value at } \\
\text { P } \leq 0.05\end{array}$ & 2.59 & 0.59 & 0.88 & 1.07 \\
\hline $\begin{array}{l}\text { Tomato } \\
\text { cultivars }\end{array}$ & \multicolumn{5}{|l}{} \\
\hline Roma & $53.13 \mathrm{c}$ & $6.41 \mathrm{~b}$ & $40.42 \mathrm{bc}$ & $46.92 \mathrm{~b}$ \\
\hline Roma VF & $52.79 \mathrm{c}$ & $6.03 \mathrm{bc}$ & $40.58 \mathrm{~b}$ & $46.83 \mathrm{~b}$ \\
\hline $\begin{array}{l}\text { Super } \\
\text { Classic }\end{array}$ & $51.87 \mathrm{c}$ & $5.71 \mathrm{c}$ & $41.00 \mathrm{~b}$ & $46.58 \mathrm{~b}$ \\
\hline Bambino & $63.09 \mathrm{a}$ & $6.29 \mathrm{~b}$ & $43.33 \mathrm{a}$ & $49.42 \mathrm{a}$ \\
\hline Riogrand & $60.47 \mathrm{~b}$ & $6.98 \mathrm{a}$ & $39.75 \mathrm{c}$ & $45.75 \mathrm{~b}$ \\
\hline $\begin{array}{l}\text { LSD value at } \\
\text { P } \leq 0.05\end{array}$ & 2.32 & 0.44 & 0.83 & 1.20 \\
\hline N x Cultivars & Ns & Ns & Ns & Ns \\
\hline
\end{tabular}

$\mathrm{N} \mathrm{ha}^{-1}$, which was statistically different from other treatments. The lowest number of fruits plant $^{-1}$ (21.82) was produced by control treatment. There were statistically significant differences among tomato cultivars as well as nitrogen levels for number of fruit plant ${ }^{-1}$ (Table 2). The interaction between the two factors, however, was non significant.

Number of fruits plant ${ }^{-1}$ gradually increased with increasing levels of nitrogen up to $150 \mathrm{Kg} \mathrm{N} \mathrm{ha}^{-1}$ treatment [11]. Sharma [21] also found highest number of fruits plant ${ }^{-1}$ with $120 \mathrm{~kg} \mathrm{~N} \mathrm{ha}^{-1}$. The difference in number of fruit plant ${ }^{-1}$ of tomato varieties suggests that there is considerable genetic variability among the tested genotypes. It was observed that the application of $\mathrm{N}$ up to $150 \mathrm{~kg} \mathrm{ha}^{-1}$ increased number of fruits plant ${ }^{-1}$ and further addition of $\mathrm{N}$ decreased the number of fruits plant ${ }^{-1}$.The results are in close association with those of Haque et al. [11] and Banerjee et al., [22] who reported the highest number of fruits plant ${ }^{-1}$ from the plots fertilized with 120 and $125 \mathrm{~kg} \mathrm{~N} \mathrm{ha}^{-1}$, respectively.

\section{Fruit length (cm)}

Longer fruits $(5.97 \mathrm{~cm})$ were obtained from the plots fertilized with $150 \mathrm{~kg} \mathrm{ha}^{-1}$ nitrogen whereas; smaller $(5.07 \mathrm{~cm})$ fruits were obtained when $200 \mathrm{~kg}$ $\mathrm{ha}^{-1}$ nitrogen was applied. Similarly in case of cultivars, cultivar Bambino showed longer fruit length $(6.04 \mathrm{~cm})$ and Roma VF showed smaller fruit length $(5.27 \mathrm{~cm})$ (Table 2). Interaction between 
tomato varieties and nitrogen levels was recorded as non significant.

Fruit length is a character highly influenced by nitrogen levels. Sainju et al. [20] reported that nitrogen deficiency in tomato can result in stunted growth and decrease fruit number and size. Winsor and Massey, [23] found that the highest nitrogen treatment $(275 \mathrm{ppm})$ reduced the proportion of high grade tomato fruit. Also, low nitrogen concentration increased the high grade fruits and the fruit size. These results confirmed the previous findings of Nathulal and Pundrik, [24] and Dod et al., [25] who reported significant increase in fruit length with increased nitrogen levels reaching maximum at 100 $\mathrm{kg}$ and at $125 \mathrm{~kg} \mathrm{~N} \mathrm{ha}^{-1}$, respectively. Singh and Srivasta [26] also reported that application of $120 \mathrm{~kg}$ $\mathrm{N} \mathrm{ha}{ }^{-1}$ significantly increased length of chilli fruits $(6.10 \mathrm{~cm})$ over control treatment $(4.68 \mathrm{~cm})$.

\section{Fruit width (cm)}

The thickest fruits $(5.02 \mathrm{~cm})$ were obtained from the plots when $200 \mathrm{~kg} \mathrm{ha}^{-1}$ nitrogen was used. Less fruits width $(4.45 \mathrm{~cm})$ was obtained from control plots. Similarly in case of cultivars, Super classic showed more width $(5.07 \mathrm{~cm})$ and Roma showed smaller fruit width $(4.39 \mathrm{~cm})$. Tomato cultivars as well as nitrogen levels disclosed significant variability for fruit width as evident from the analysis of variance (Table 2). Interaction between the factors was considered as non significant.

The results indicated that the application of nitrogen provided thicker fruits which ultimately resulted in greater yield. Fruit width blows directly the final yield in tomato. Imas, [27] and Zekri and Obreza, [28] reported that low concentrations of $\mathrm{N}$ will result in smaller fruit since the rate of photosynthetic activity of the plant will drop sharply therefore, growth was reduced and smaller fruits was produced. Our results are in concurrence with that of Subramanian et al. [29], who reported that fruit quality (length, girth and weight) increased with increasing nitrogen application rate.

Yield ( ha $\left.^{-1}\right)$

Maximum yield (29.65 $\left.\mathrm{t} \mathrm{ha}^{-1}\right)$ was produced by Riogrand whereas; minimum (19.24 $\mathrm{t} \mathrm{ha}^{-1}$ ) was produced by Roma vf. In case of nitrogen levels, maximum yield $\left(27.54 \mathrm{t} \mathrm{ha}^{-1}\right)$ was obtained from the plots fertilized with $150 \mathrm{~kg} \mathrm{~N} \mathrm{ha}{ }^{-1}$ while, minimum (21.50 $\mathrm{t} \mathrm{ha}^{-1}$ ) was obtained from control plot. There were statistically significant differences among tomato cultivars as well as nitrogen levels for fruit weight (Table 2). The interaction between the two factors, however, was non significant.

Overall yield and its components were normally more responsive to application of $\mathrm{N}$ [30]. However, tomato is highly responsive to $\mathrm{N}$, but an excessive rate of $\mathrm{N}$ application is seldom adversely affects tomato quality [31]. Olasantan [32] also found that fruit yield of the tomato plant was reduced at higher $\mathrm{N}$ application rates. Sainju et al. [33] concluded that marketable yields were maximized at $\mathrm{N}$ rates of $180 \mathrm{~kg} \mathrm{~N} \mathrm{ha}^{-1}$. The difference in fruit yield of tomato varieties suggests that there is considerable genetic variability among the tested genotypes. Our results are in close association with those of Haque et al. [11] and Banerjee et al. [22] who reported the highest fruit yield from the plots fertilized with 120 and $125 \mathrm{~kg} \mathrm{~N} \mathrm{ha}^{-1}$, respectively. Pandey et al. [7], however, obtained increase in fruit yield up to level of $80 \mathrm{~kg} \mathrm{~N} \mathrm{ha}{ }^{-1}$. The difference in results of different scientist may due the different response of the varieties to the nitrogen. Other reasons could be the difference in nitrogen availability, cropping pattern and soil structure among the experimental plots.

Table-2: Number of fruits plant-1, fruit length $(\mathrm{cm})$, fruit width (cm) and yield (tons ha-1) of tomato cultivars as affected by different $\mathrm{N}$ levels.

\begin{tabular}{|c|c|c|c|c|}
\hline $\begin{array}{l}\text { Treatments } \\
\mathbf{N} \text { Levels }\end{array}$ & $\begin{array}{l}\text { Number } \\
\text { of fruits } \\
\text { plant }^{-1}\end{array}$ & $\begin{array}{l}\text { Fruit } \\
\text { length } \\
(\mathrm{cm})\end{array}$ & $\begin{array}{l}\text { Fruit } \\
\text { width } \\
(\mathrm{cm})\end{array}$ & $\begin{array}{c}\text { Yield (tons } \\
\mathrm{ha}^{-1} \text { ) }\end{array}$ \\
\hline 0 & $21.82 \mathrm{~d}$ & $5.43 \mathrm{bc}$ & $4.45 \mathrm{~b}$ & $21.50 \mathrm{~d}$ \\
\hline 100 & $23.18 \mathrm{c}$ & $5.73 \mathrm{ab}$ & $4.79 a$ & $24.12 \mathrm{c}$ \\
\hline 150 & $25.53 \mathrm{a}$ & $5.97 \mathrm{a}$ & $4.91 \mathrm{a}$ & $27.54 a$ \\
\hline 200 & $24.01 b$ & $5.07 \mathrm{c}$ & $5.02 \mathrm{a}$ & $25.61 b$ \\
\hline $\begin{array}{l}\text { LSD value } \\
\text { at } \mathrm{P} \leq 0.05\end{array}$ & 0.62 & 0.38 & 0.28 & 0.95 \\
\hline \multicolumn{5}{|l|}{$\begin{array}{l}\text { Tomato } \\
\text { cultivars }\end{array}$} \\
\hline Roma & $22.38 d$ & $5.33 b$ & $4.39 b$ & $23.19 \mathrm{c}$ \\
\hline Roma VF & $18.76 \mathrm{e}$ & $5.27 \mathrm{~b}$ & $4.44 b$ & $19.24 \mathrm{~d}$ \\
\hline $\begin{array}{l}\text { Super } \\
\text { Classic }\end{array}$ & $23.34 \mathrm{c}$ & $5.66 \mathrm{ab}$ & $5.07 \mathrm{a}$ & $24.12 \mathrm{c}$ \\
\hline Bambino & $26.09 \mathrm{~b}$ & $6.04 \mathrm{a}$ & $5.03 \mathrm{a}$ & $27.28 b$ \\
\hline Riogrand & $27.61 \mathrm{a}$ & $5.45 \mathrm{~b}$ & $5.06 \mathrm{a}$ & $29.65 a$ \\
\hline $\begin{array}{l}\text { LSD value } \\
\text { at } \mathrm{P} \leq 0.05\end{array}$ & 0.85 & 0.45 & 0.31 & 1.23 \\
\hline $\begin{array}{ll}\mathrm{N} & \mathrm{X} \\
\text { Cultivars } & \\
\end{array}$ & Ns & Ns & Ns & Ns \\
\hline
\end{tabular}

\section{Reference}

1. Rudich, J. and J. G. Atherton. 1986. Botany of tomato crop. In "The Tomato Crop". 6th Ed. Mac Millan Pub. Co., New York. p: 221-222.

2. Anonymous, 2003. Agric. Stat. Ministry of Agric. India.

3. Malik, M. 1994. Hort. (Ist Edition) National Book Foundation. 508-509.

4. Splittstoesser, W. E. 1990. Vegetable Growing Hand Book, Organic and Traditional Methods 3rd Ed. Van Nostrand Reinhold, New York. p. 5.

5. Mehla, C. P., V. K. Srivastava. S. Jage. R. Mangat. J. Singh and M. Ram. 2000. Response of tomato varities 
to $\mathrm{N}$ and $\mathrm{P}$ fertilization and spacing. Ind. J. Agri. Res. 34(3): 182-184.

6. Sharma, K. C., A. K. Singh and S. K. Sharma, 1999. Studies on Nitrogen and Phosphorus requirement of tomato hybrids. Annals Agri. Res. 20 (4): 339-402.

7. Pandey, R. P., P. N. Solanki. R. K. Saraf and M. S Parihar. 1996. Effect of Nitrogen and Phosphorus on growth and yield of tomato varieties. Punjab Vege. Grower. 31: 1-5.

8. McNeal, B. L., C .D. Stanley, W. D. Graham, P. R. Gilreath, D. Downey and J. F. Creighton. 1994. Nutrient-loss trends for vegetable and citrus fields in West-Central Florida: I. Nitrate. J. Environ. Qual. 24: 95-100.

9. Steel, R. G. D. and J. H. Torrie, 1980. Principles and procedures of statistics. A biometrical approach. $2^{\text {nd }}$ Ed., McGraw Hill Inter. Book Co. Tokyo, Japan

10. Baloch M. A., A. F. Baloch, G. Baloch, A. H. Ansari and S. M. Qayyum. 1991. Growth and yield response of onion to different nitrogen and potassium fertilizer combination levels. Sarhad J. Agric. 7(1): 63-66

11. Haque, M. E., A. K. Paul and J. R. Sarker. 2011. Effect of Nitrogen and Boron on the Growth and Yield of Tomato (Lycopersicon esculentum L.). Intern. J. Bioresource Stress Manag. 2(3): 277-282.

12. Ali, M. H., A. M. Rahman and M. J. Ullah. 1990. Effect of plant population and nitrogen on yield and oil content of rape seed (Brassica campestris). Ind. J. Agric. Sci. 60(9): 627-630.

13. Mondal, M. R. I. and M. A. Gaffer. 1983. Effect of different levels of nitrogen and phosphorus on the yield and yield contributing characters of mustard. Bang. J. Agric. Res. 8(1): 37-43.

14. Gaffer, M. A. and A. H. M. Razzaque. 1983. Response of mustard to different levels of $\mathrm{N}, \mathrm{P}, \mathrm{K}$ fertilizers under two methods of seeding. Bangladesh Association for the Advancement of Sci. Dhaka. In: Proceeding 8th Bang. Sci. Conference BAAS, Dhaka, Bangladesh.

15. Olasantan, F. O. 1991. Response of tomato and okra to nitrogen fertilizer in sole cropping and intercropping with cowpea. J. Horti. Sci. 66: 191-199.

16. Dass, R. C. and S. N. Mishra, 1972. Effect of nitrogen, phosphorus and potassium on growth, yield and quality of chilli (Capsicum annuum L.). Plant Sci. 4: 78-83.

17. Khan, M. A. R. and N. Suryanarayana. 1977. Effect of NPK on flowering, fruit size and yield of chilli cultivar NP-46A. Vege. Sci. 4(1): 55-60.

18.Law-Ogbomo, K. E. and R. K. A. Egharevba. 2009. Effects of Planting Density and NPK Fertilizer Application on Yield and Yield Components of Tomato (Lycospersicon esculentum L.) in Forest Location. World J. Agric. Sci. 5(2): 152-158.

19. Addae-Kagay, K. A. and J. C. Norman 1977. The influence of nitrogen levels on local cultivars of eggplan. Acta. Horti. 2(53): 397-401.
20.Sainju, M., R. Dris and B. Singh. 2003. Mineral nutrition of tomato. Food Agric. Environ. 1(2): 176183.

21. Sharma, K. C., A. K. Singh and S. K. Sharma, 1999. Studies on Nitrogen and Phosphorus requirement of tomato hybrids. Annals Agri. Res. 20 (4): 339-402.

22. Banerjee, M. K.., D. S. Balyan, G. Kalloo, S. Azad, P. S. Saini and A. Singh. 1997. Effect of nitrogen fertilization and planting pattern of fruit yield of tomato cv. Hisar Lalima (Sel-18). Crop Res. 14(3): 441-446.

23. Winsor, W. and M. Massey. 1978. Some aspects of the nutrition of tomatoes grown in recirculating solution, Acta Horti. 82: 121-132.

24. Nathulal and Pundrik, K. C. 1971. Effect of nitrogen, phosphorus and potassium on the growth and yield of chilli (Capsicum frutescens L.). Punjab Horti. J. 11(1/2): 82-88.

25. Dod, V. N., A. T. Joshi, P. B. Kale and J. Kurlwal,. 1983. Effect of different levels of nitrogen in split doses on yield and quality of red ripe chillies (Capsicum annuum L.) cv. G-3. Proceedings of National Seminar on Production Technology of Tomato and Chillies, Tamil Nadu Agric. Uni. Coimbatore.

26. Singh, K and B. K. Srivastava. 1988. Effect of various levels of nitrogen and phosphorus on growth and yield of chilli. Ind. J. Horti. 45(4): 319-324.

27. Imas, P. 1999. Quality aspects of $\mathrm{K}$ nutrition in horticultural crops. Proceedings of the IPI-PRII-KKV work shop on the recent trends in nutrition manag. in Hort. Crops. Ind.

28.Zekri, M. and A. Obreza. 2003. Plant nutrients for citrus trees, Soil and Water Science Dept. Inst. Food and Agric. Sci. Uni. of Florida, fact sheet SL 200.

29. Subramanian, K. S., K. V Selvaraj, G. Selvakuman and V. S. Shanmugasundaram. 1993. Influence of moisture regimes and nitrogen on growth and yield of brinjal (Solannon inelongena L.). South Ind. Horti. 41(1): 1621.

30.Badr M. A and A. A. El-Yazied. 2007. Effect of fertigation frequency from subsurface drip irrigation on tomato yield grown on sandy soil. Aust. J. Basic Applied Sci. 1(3): 279-285.

31. Huett, D. O. and E. B. Dettmann.1988. Effect of nitrogen on growth, fruit quality and nutrient uptake of tomatoes grown in sand culture. Aust. J. Experi. Agri. 28(3): 391-399.

32. Olasantan, F. O. 1991. Response of tomato and okra to nitrogen fertilizer in sole cropping and intercropping with cowpea. J. Horti. Sci. 66: 191-199.

33. Sainju, U. M., B .P. Singh and W. F. Whitehead. 2001. Comparison of the effects of cover crops and nitrogen fertilization on tomato yield, root growth, and soil properties. Sci. Horti. 91: 201-214. 